\title{
CORRECTION
}

\section{Correction to: Effect of process parameters on surface roughness of hybrid investment casting}

\author{
Parlad Kumar $^{1} \cdot$ Inderpreet S. Ahuja ${ }^{1} \cdot$ Rupinder Singh ${ }^{2}$
}

Published online: 4 May 2020

○) Springer Nature Switzerland AG 2020

\section{Correction to: Prog Addit Manuf (2016) 1:45-53 https://doi.org/10.1007/s40964-016-0004-9}

Publisher's Note Springer Nature remains neutral with regard to jurisdictional claims in published maps and institutional affiliations.

The publication of this article unfortunately contained a mistake. Reference 1 was not correct, please see the corrected reference below.

\section{Reference}

Chua CK, Leong KF, Lim CS (2010) Rapid prototyping: principles and applications, third edition. World Scientific, Singapore

Rupinder Singh

rupindersingh78@yahoo.com

Parlad Kumar

pkgarg4050@gmail.com

Inderpreet S. Ahuja

ahujaips@yahoo.co.in

1 Department of Mechanical Engineering, Punjabi University, Patiala, Punjab, India

2 Department of Production Engineering, Guru Nanak Dev Engineering College, Ludhiana, Punjab, India 